\title{
Reflets
}

Revue ontaroise d'intervention sociale et communautaire

\section{Le vent du large}

\section{Carole Labrèche}

Volume 6, numéro 2, automne 2000

Problèmes sociaux en Ontario français

URI : https://id.erudit.org/iderudit/026322ar

DOI : https://doi.org/10.7202/026322ar

Aller au sommaire du numéro

Éditeur(s)

Reflets : Revue ontaroise d'intervention sociale et communautaire

ISSN

1203-4576 (imprimé)

1712-8498 (numérique)

Découvrir la revue

Citer ce document

Labrèche, C. (2000). Le vent du large. Reflets, 6(2), 222-222.

https://doi.org/10.7202/026322ar

Tous droits réservés (C) Reflets : Revue ontaroise d'intervention sociale et communautaire, 2000

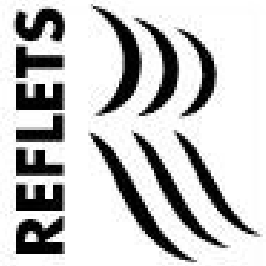

Ce document est protégé par la loi sur le droit d'auteur. L'utilisation des services d'Érudit (y compris la reproduction) est assujettie à sa politique d'utilisation que vous pouvez consulter en ligne.

https://apropos.erudit.org/fr/usagers/politique-dutilisation/ 


\section{Le vent du large}

\section{Carole Labrèche}

Le vent du large t'appelle

Elle disait souvent : "Goûte le vent salé sur tes lèvres "

Le vent du large m'appelle

Je me souviens d'elle...

Grande voyageuse du subconscient

Elle était là et ailleurs en même temps

Comme si elle cherchait toujours l'autre moitié d'elle-même

En panne de mots

Elle ne pouvait plus vivre à la surface des autres...

Alors elle promenait ses idées un peu partout

Quelque fois, jusqu'au bord de la falaise

Et je tremble à l'idée

Qu'elle joua peut-être à pile ou face là-haut

Au large des côtes, quand la marée est haute

On croit encore entendre ses paroles :

Mayday! Mayday! M’aider! May... 